\title{
Portable Rice Hull Stove: An Innovation*
}

\author{
Eduardo Zeta Ramis \\ Technology Department, University of Eastern Philippines, Catarman, Philippines \\ Email: edz ramis@yahoo.com
}

Received 3 September 2014; revised 24 October 2014; accepted 25 November 2014

Copyright (C) 2014 by author and OALib.

This work is licensed under the Creative Commons Attribution International License (CC BY). http://creativecommons.org/licenses/by/4.0/

\section{(c) (i) Open Access}

\section{Abstract}

This research is an innovation of the portable rice hull stove equipment to save time, investment, manpower and the environment. A desired distance of $5 \mathrm{~cm}$ bottom height of the inside burner from ash retainer is obtained as the critical point in achieving the best combustion process. The unique characteristic of this innovative design is the perforated inside and outside burners and the detachable inside burner for easy replacement and durability of this stove. Specifically, this rice hull stove consists of eleven major parts to wit: 1) inside burner \& holder; 2) hopper; 3) flame controller; 4) combustion chamber; 5) outer burner; 6) tensioner (optional); 7) pot (base) rest; 8) retainer of rice hull fuel; 9) perforated holes (natural air supply); 10) leverage (optional) for ash/ aeration and disposal in the ash/char chamber); and 11) tripod stand. For easy removal of the ash and char in the stove at the ash chamber, a flat floppy type ash remover was keenly studied and observed through hand and or foot tapping of the leverage for every 2- to 5-minute combustion. The workability of the equipment was tested through an actual cooking utilizing the different input cooking materials like clean rice, fish, etc., and different weights of rice hull fuel. The rice hull stove has the following thermal efficiencies: for clean rice, it is $\mathbf{9 . 7 6 \%}$; for drinking water, it is

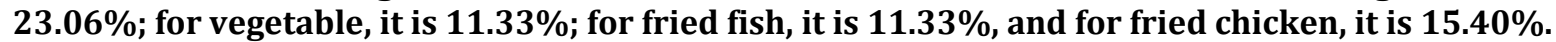

\section{Keywords}

Portable Stove, Portable Rice Hull Stove, Biomass Stove, Rice Husk Stove

Subject Areas: Agricultural Engineering, Industrial Engineering

\section{Introduction}

\subsection{Rationale}

This innovation is timely studied due to the high cost of cooking gas for application in cooking food and for animal consumption. This is a low cost investment, affordable for the low-income sector of the country. This

*Tire (inflatable inner tube) vulcanizing equipment. 
stove is environment friendly, and its wastes can be utilized as soil conditioners (carbonized rice hull— $\mathrm{RCH}$ ); as cement additive and solar panel ingredients (rice hull ash—RHA); as insect repellant; and as bottle and plastic cleanser.

This rice hull as a source of fuel is very cheap and the stove itself is also inexpensive. The origin of the design is unknown. Some sources mention Cambodia, other sources said, Vietnam. After a Vietnamese scholar had brought a unit from Vietnam for testing in IRRI Philippines, many nationals' systems and projects have adopted the technology to local conditions and similar stoves can now be found in most Asian countries (IRRI.org).

\subsection{General Objectives}

The product or output of this study may help the family household in reducing the high cost of cooking fuels and stoves. This study can boost up the economy, particularly in the countryside.

This new design of a portable rice hull stove and its material components is for kitchen and cooking application. Thermal efficiency of this stove is computed as well as its economic viability and application for kitchen and cooking application in terms of fuel consumption.

\subsection{Specific Objectives}

Specifically, this study is conducted to:

1) identify the new design of a portable rice hull stove for kitchen and cooking application;

2) determine the material components of the portable rice hull stove application for kitchen and cooking application;

3) find out the thermal efficiency of the portable rice hull stove application for kitchen and cooking application in terms of fuel consumption;

4) find out the economic viability of the portable rice hull stove application for kitchen and cooking application in terms of fuel consumption.

\subsection{Specific Basis/Theoretical Framework}

McClelland [1] classifies people in relation to their dominant need for achievement, power of affiliation, as viewed by successful entrepreneurs. McClelland explains that "people who are high in need achievement are highly motivated to strive for the satisfaction that is derived from accomplishing a trade or occupation which is most of the time a challenging task". In the design and fabrication of the rice hull stove, one must possess patience, endurance and dexterity, qualities present on the individuals who are graduates of technical education.

A. T. Belonio, Damiel A. H. Belonio, and Lucio Larano [2] state that alternative energy sources, for example, the use of biomass is of interest to people from around the world. This is because the supply of fossil fuel is becoming scarce causing the price to be costly both for the domestic and industrial sectors. Rice husk, which is one of the biomass fuel sources around the world, is still considered untapped. Gasifying rice husk which burns it with limited amount of air is found to be an effective means of generating heat that can be utilized for various applications.

\section{Review of Related Literature}

\subsection{What Is Rice Husk?}

The outermost layer of the paddy grain is the rice husk, also called rice hull. It is separated from the brown rice in rice milling. Burning rice husk produces rice husk ash (RHA), the burning process is incomplete carbonized rice husk (CRH) is produced.

Around $20 \%$ of the paddy weight is husk. In 2008 the world paddy production was 661 million tons and consequently 132 million tons of rice husk were also produced. While there are some uses of rice husk, it is still often considered a waste product in the rice mill and therefore often either burned in the open or dumped on wasteland. Husk has a high calorific value and therefore can be used as a renewable fuel [3].

Rice husk is produced in the first step in the milling process when the husk is removed from the grain in the husking stage of the rice mill. 


\subsection{Utilization of Rice Husk and Rice Husk Ash}

Rice husk is produced centrally at rice mills and has low moisture content since the paddy is dried to $14 \%$ or less before milling. The disadvantage is that rice husk has very low density and therefore its transport over longer distance is expensive. The most important use of rice husk is its use as fuel, but it is also used for some non-energy purposes.

The cultivation of rice results in two major types of residues—straw and hull/husk having attractive potential in terms of energy. Although the technology for rice husk utilization is well-proven in industrialized countries of Europe and North America, such technologies are yet to be introduced in the developing world on commercial scale.

Zafar [4] states that the importance of rice husk and rice straw as an attractive source of energy can be gauged from following statistics: 1) rice straw: 1 ton of rice paddy produces $290 \mathrm{~kg}$ rice straw; $290 \mathrm{~kg}$ rice straw can produce $100 \mathrm{kWh}$ of power; calorific value $=2400 \mathrm{kcal} / \mathrm{kg}$; and 2) rice husk: 1 ton of rice paddy produces 220 $\mathrm{kg}$ rice husk; 1 ton rice husk is equivalent to 410 - $570 \mathrm{kWh}$ electricity; calorific value $=3000 \mathrm{kcal} / \mathrm{kg}$; moisture content $=5 \%-12 \%$. Some of the hulls produced by small rice mills are used as domestic fuel or livestock feed (when mixed with rice bran) and vast quantities of rice husk are not utilized and are disposed of in vacant areas or along roadsides and highways. On the other hand Beagle [5] states that the energy content of rice hulls is 13 to $16 \mathrm{MJ} / \mathrm{kg}$; 1600 - $6800 \mathrm{BTU} / \mathrm{lb}$; a ton of rice hulls is equal to about 84 gallons of heating oil having 140,000 BTU/gal.

\subsection{Rice-Hull Stoves}

The unmindful cutting of trees for firewood, poles and other uses has depleted available resources in most barangays. Lowland areas are particularly affected as areas are cleared for paddy rice and/or vegetable production.

The increasing price of firewood demands the need to search for fuel wood substitutes. Rice hull, often regarded as a waste product of rice processing, can be the answer to such a quest. Rice hulls can be obtained free or at very minimal costs. Promoting the use of this stove will conserve valuable tree resources.

E. U. Bautista, et al. [6], stated that there are $14 \%$ - 16\% harvested weight paddy. Philippine paddy production is equal to 9 metric tons (Mt). Some $1.8 \mathrm{Mt}$ rice hull is produced each year in the country.

The study of Pare [7], revealed that the performance of stoves requires $0.8 \mathrm{~kg}$ of char as filler rice husk as fuel in one full load. The fuel consumption of the stove is at an average rate of $2.6 \mathrm{~kg}$ of rice husk per hour. Combustible gas is produced within 5 to 10 minutes on ignition of fuel. One and a half liter of water can be boiled within 14 to 20 minutes.

Belonio \& Ligisan E, [8], their study, found out that rice husk has a low $\mathrm{CO}_{2}$ equivalent to $0.6 \mathrm{~kg} \mathrm{CO} / \mathrm{kg}$ of rice husk. Further on their finding, there is a black carbon of $50 \mathrm{ug} / \mathrm{m}^{3}$ emission only.

\section{Related Studies}

In another related study of Lockman, et al., [9] their design is described as a rice husk gasification stove that provides usable cooking heat in 10 - 20 minutes batches. The construction of the stove is one that features rounded sheet metal cylinder that is easy to make in Villa Catalina as well as a cook top that allows pots to sit inside it, enabling greater heat transfer. The cooking surface is designed to accommodate existing pots and is capable of cooking the range of Nicaraguan dishes.

These cooking stoves come in different sizes and usually can boil a pot of water in around 10 - 15 minutes. The fuel is cheap and the stove itself very inexpensive but the disadvantage is that the user is exposed to small, silica rich ash particles in the fuel gas.

To generate a cleaner flame, the cooking stove principle was modified into a gasifier burner that has a clean flame. Commercial applications exist in the Philippines and in India.

\subsection{The Rice Hull Gasification Stove}

Another related study points out that using rice husk furnaces for heating the drying air in rice dryers is the most obvious application for using rice husk since the husk is available as waste the rice mill and drying of paddy is often done by millers. But only recently with increasing fossil fuel prices, there has been a major shift away 
from kerosene towards rice husk furnaces. In India and Bangladesh, rice husk is often used as fuel for parboiling paddy before milling [3].

\subsection{Advantages \& Disadvantages of Using Rice Hull}

The benefits of using rice husk technology are numerous. Primarily, it provides electricity and serves as a way to dispose of agricultural waste. In addition, steam, a by-product of power generation, can be used for paddy drying applications, thereby increasing local incomes and reducing the need to import fossil fuels. Rice husk ash, the by-product of rice husk power plants, can be used in the cement and steel industries further decreasing the need to import these materials. Rice straw can either be used alone or mixed with other materials in direct combustion. In this technology, combustion boilers are used in combination with steam turbines to produce electricity and heat. The energy content of rice straw is around $14 \mathrm{MJ}$ per $\mathrm{kg}$ at 10 percent moisture content. The by-products are fly ash and bottom ash, which have an economic value and could be used in cement and/or brick manufacturing, construction of roads and embankments, etc. Straw fuels have proved to be extremely difficult to burn in most combustion furnaces, especially those designed for power generation [3].

According to Zafar [9] the primary issue concerning the use of rice straw and other herbaceous for power generation is fouling, slagging, and corrosion of the boiler due to alkaline and chlorine components in the ash. Europe, and in particular, Denmark, currently has the greatest experience with straw fired power and CHP plants.

\section{Methodology}

This section discusses the processes that were done and the tools that were used during the experiment. The study utilized experimental research method which includes the materials and equipment used, research design and layout, fabrication procedures, testing procedures, data analysis and benefit/cost analysis.

\subsection{Materials and Equipment Used}

The materials (steel plate, steel bars, etc.) were used to shape-up the portable rice hull stove. The parts were collected, measured and welded; holes were bored in the inside and outside combustion chambers; and in the ash chamber before these were assembled.

The materials to be used in assembling of the portable rice hull stove are the following:

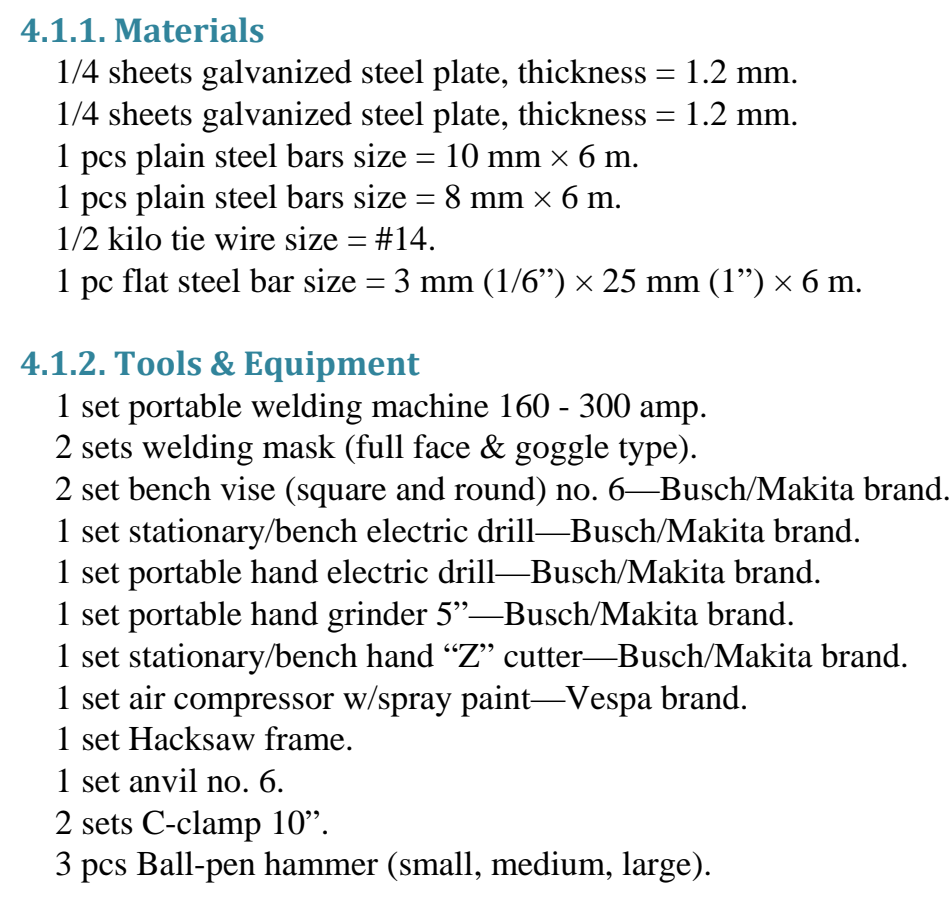


1 pc 12 ” thinner snips.

\subsubsection{Consumables}

1 pcs 5 ” grinder blade — coarse (portable hand grinder).

1pcs 5" grinder blade—fine (portable hand grinder).

1 kilo welding rods.

2 pairs working gloves.

1 box rivets (assorted sizes).

1 box hacksaw blade (sandflex/bacho).

These are the materials needed in shaping the portable rice hull stove. The parts were measured and welded, holes were bored for aeration, and finally the finished product was assembled.

This study was conducted during the school year 2010-2013 at the Bachelor of Technology Department, College of Engineering, University of Eastern Philippines, University Town, Northern Samar.

Specifically, this rice hull stove consists of eleven major parts (please refer to Figure 1) as: 1) inside burner \& holder, the outlet of the burned gasses 2) hopper - the loading area and depository of the rice hull fuels, 3) flame controller - to minimize/control the flow of gas, 4) combustion chamber, the place where burning of rice fuel takes place 5) outer burner, serves as the holding area of the rice fuel, 6) tensioner, (optional) —an spring used for easy foot pedal operation 7) pot (base) rest, where the cooking utensils are placed during cooking operation, 8) retainer of rice hull fuel, serves as guide of rice hull not to cover the outlet of gases from the inside burner, 9) perforated holes (natural air supply), used as air ventilator to supply natural air to the combustion chamber, 10) leverage (optional) for ash/aeration and disposal in the ash/char chamber)—a rod device connected to the end portion of the floopy disc and 11) tripod stand-is the support of the body of the stove. For comfortable removal of the ash and char in the stove at the ash chamber, a design of a flat floppy type ash remover is seriously considered through hand and or foot tapping of the leverage for every 2 to 5 minutes combustion.

Figure 1 below shows the fabrication of the portable rice hull stove with labeled parts.

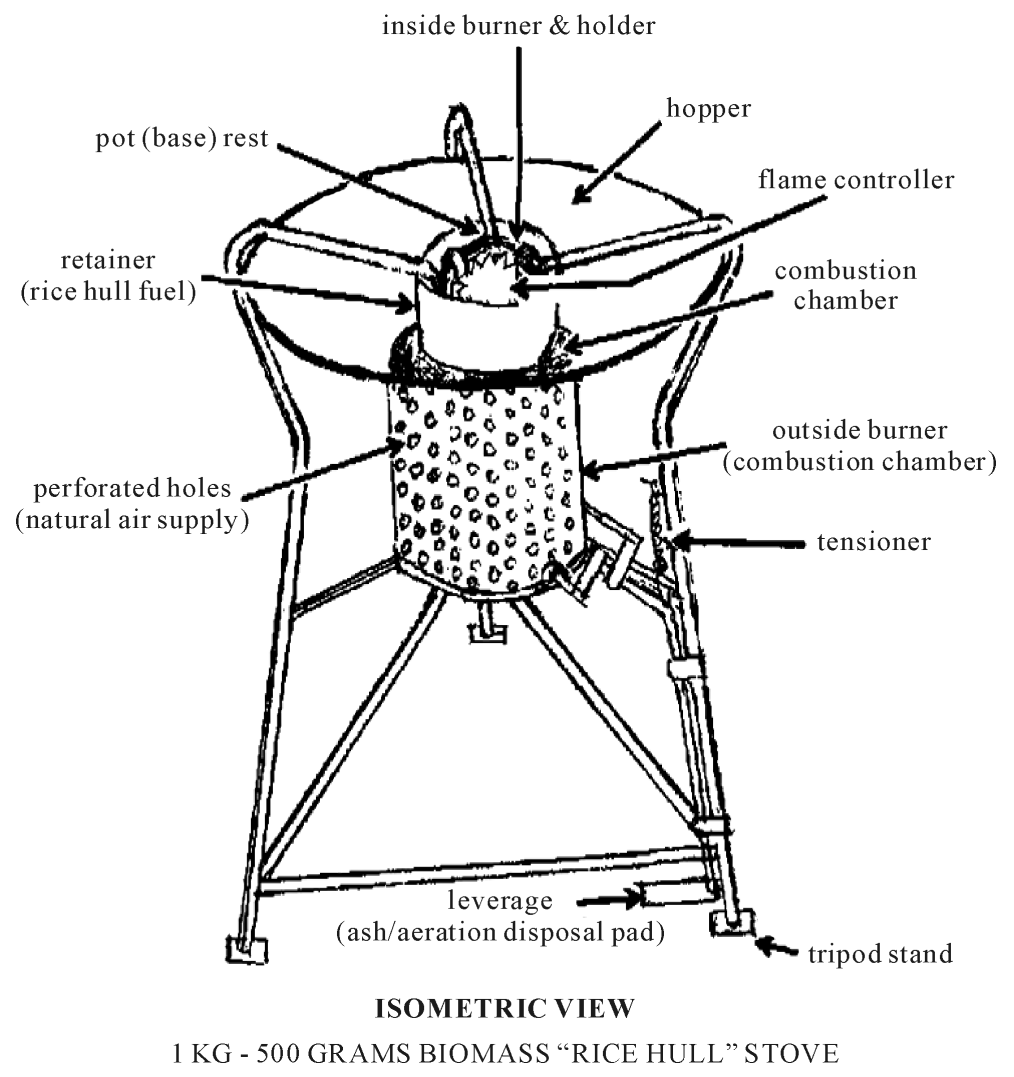

Figure 1. Isometric view of rice hull stove. 


\subsection{Research Design and Layout}

The study utilized experimental research method which includes the materials and equipment used, research design and layout, fabrication procedures, testing procedures, data analysis and benefit/cost analysis.

This innovative design of the rice hull stove was based on its portability and light weight, and its ease in operation. The features of this portable rice hull stove are as follows:

- The stove weight 5.75 kilograms; measuring $70 \mathrm{~cm}$ in height, $47 \mathrm{~cm}$ in width for the100-gram capacity stove and $4.10 \mathrm{kgs}$ for the 500-gram capacity stove and most importantly it is environment-friendly.

- Its body configuration is an expanded cone/funnel appearance. A movable leverage is welded at the bottom/ash chamber part of the stove for releasing the ashes and providing aeration to the machine. This is made of galvanize iron steel plate, gauge 22, and corrugated steel bars sized of $10 \mathrm{~mm}$ and $8 \mathrm{~mm}$, respectively.

- A cone/funnel type hopper is attached to the top portion of the stove that serves as guide in loading the rice hull as fuel.

- The tripod/base was made of steel bar with dimension of $10 \mathrm{~mm}$ in diameter and $70 \mathrm{~cm}$ in height that serves as foundation of the equipment.

- The inside burner is detachable for easy replacement with a perforated sides for adequate aeration.

- This stove rice hull stove takes only 15 minutes for 2 liters in boiling water; 21 minutes in cooking $1 \mathrm{~kg}$ rice; 29 minutes in cooking $1 / 2 \mathrm{~kg}$ of fried fish; 11 minutes in cooking vegetables.

\subsection{Fabrication Processes}

Based on the plan and design, the steel bars and galvanized steel plate were cut to their desired length then welded to form the tripod/base; the combustion chamber is designed with perforated holes inside and outside cover to provide aeration to the rice hull. Guide/stopper of rice hull fuel was constructed to prevent obstruction at the burner at the topmost portion of the combustion chamber.

\subsection{Testing Process}

Testing was undertaken to determine the workability of the stove. The completed cooking stove was tested using the rice hull as fuel by pouring it into the combustion chamberinfull capacity to the topmost portion of the hopper. Seven pieces of used coupon bond were utilized to ignite the rice hull fuel for 15 to 45 seconds ignition.

\subsection{Data Analysis}

The stove was tested with various cooking materials and the data were gathered and recorded for computations and completion of the research.

\subsection{Benefit/Cost Analysis}

Benefit and cost analysis were computed to determine the viability of the study using the following financial analysis: 1) return of investment $(\mathrm{ROI})=$ net income $(\mathrm{NI}) /$ total project cost $(\mathrm{TPC})$; 2$)$ payback period $(\mathrm{PP})=$ total project cost/average annual income (ANI); and 3) internal rate of return (IRR) = 1/PP.

\subsection{Flowchart of the Study}

Figure 2 shows the construction methods of this portable rice hull stove for kitchen and cooking application. The first step is the input which includes the steel plate, steel bar, welding, electric drill and other components in making the product; the second step is the process, the designing of the product, testing of the machine and data gathering; and the last step is the output which is the product, the portable rice hull stove.

\section{Results and Discussion}

\subsection{The New Design of the Portable Rice Hull Stove}

The new design of this portable rice hull stove cropped up as an alternative utilization of fuel. The researcher found out technical difficulties in designing the exact capacity of the combustion chamber and hopper for 


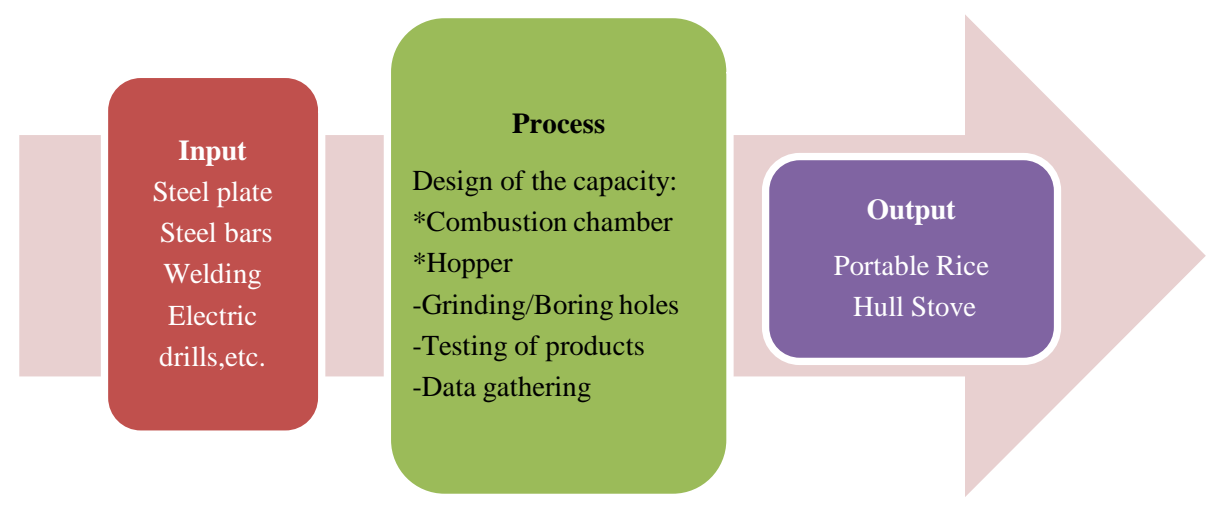

Figure 2. Flowchart of the study.

$1 \mathrm{~kg} / 500$ grams rice hull fuel. With minor flaw observed by observant stove users, this design was developed.

\subsection{The Materials Used for the Stoves}

Selection and identification of materials were seriously considered for the durability of the product.

The materials used in the assemblage of the portable rice hull stove are the following:

\subsubsection{Materials}

- $1 / 4$ sheets galvanized steel plate, thickness $=1.2 \mathrm{~mm}$.

- $1 / 4$ sheets galvanized steel plate, thickness $=1.2 \mathrm{~mm}$.

- $1 \mathrm{pc}$ plain steel bars size $=10 \mathrm{~mm} \times 6 \mathrm{~m}$.

- 1 pc plain steel bars size $=8 \mathrm{~mm} \times 6 \mathrm{~m}$.

- $1 / 2$ kilo tie wire size $=\# 14$.

- 1 pc flat steel bar size $=3 \mathrm{~mm}(1 / 6 ”) \times 25 \mathrm{~mm}(1 ”) \times 6 \mathrm{~m}$.

\subsubsection{Tools \& Equipment}

- 1 set portable welding machine 160 - 300 amp.

- 2 sets welding mask (full face \& goggle type).

- 2 set bench vise (square and round) no. 6-Busch/Makita brand.

- 1 set stationary/bench electric drill—Busch/Makita brand.

- 1 set portable hand electric drill—Busch/Makita brand.

- 1 set portable hand grinder 5"-Busch/Makita brand.

- 1 set stationary/bench hand "Z" cutter-Busch/Makita brand.

- 1 set air compressor w/spray paint—Vespa brand.

- 1 set Hacksaw frame.

- 1 set anvil no. 6 .

- 2 sets C-clamp 10".

- 3 pcs Ball-pen hammer (small, medium, large).

- 1 pc 12 ” thinner snips.

\subsubsection{Consumables}

- 1 pcs 5" grinder blade—coarse (portable hand grinder).

- 1 pcs 5 " grinder blade-fine (portable hand grinder).

- 1 kilo welding rods.

- 2 pairs working gloves.

- 1 box rivets (assorted sizes).

- 1 box hacksaw blade (sandflex/bacho).

These are the materials needed in shaping the portable rice hull stove. The parts were measured and welded, holes were bored for aeration, and finally the parts were assembled. 


\subsection{Thermal Efficiency of the Portable Rice Hull Stove}

Table 1 shows the energy requirements (thermal efficiency) of the different food that were used in the study.

The rice hull stove has the following energy requirements (thermal efficiency) as shown in Table 5. For clean rice, the thermal efficiency is $9.76 \%$; for drinking water, $23.06 \%$; for vegetable, $11.33 \%$; for the fried fish, 11.33\%; and for fried chicken, $15.40 \%$.

\subsection{Economic Viability of the Rice Hull Stove}

Table 2 to Table 4 illustrate the different weight, time and expenses expended in the three types of fuel for cooking applications and thermal efficiency.

In Table 2, $1.0 \mathrm{~kg}$ clean rice was cooked in 21 minutes with 700 grams of rice hull fuel of no cost. The 4 kilograms of drinking water was boiled in 15 minutes with 600 grams of rice hull fuel. One (1) kg vegetable was cooked in 11 minutes with $1 \mathrm{~kg}$ of rice hull fuel. A 500-gram fresh fish was fried-cooked in 29 minutes with 1013 grams of rice fuel and a 750 fresh chicken was fried-cooked in 34 minutes with 405 grams of rice hull fuel.

In Table 3, one (1.0) kg clean rice was cooked in 40 minutes using 500 grams of charcoal fuel with monthly cost of Php 562.25. Four (4) kilograms of drinking water was boiled in 8 minutes using 400 grams of charcoal fuel with monthly cost of Php 225.00. One (1) kg vegetables was cooked in 28 minutes using 400 grams of charcoal fuel with a monthly cost of Php 450.00. A 500-gram fresh fish was fried-cooked in 16.88 minutes using 225 grams of charcoal fuel with monthly expenses of Php 265.50 and a 750 fresh chicken was fried-cooked in 25.32 minutes using 375 grams of charcoal fuel with a monthly expense of Php 427.00.

In Table 4, one (1) kg clean rice was cooked in 37.5 minutes using $151.25 \mathrm{ml}$ of kerosene fuel with monthly cost of Php 784.20. Four (4) kilograms of drinking water was boiled in 34.4 minutes using $34.50 \mathrm{ml}$ of kerosene fuel with monthly cost of Php 192.60. One (1) kg vegetables was cooked in 22 minutes using $101.34 \mathrm{ml}$ of kerosene fuel with a monthly cost of Php 506.00.

A 500-gram fresh fish was fried-cooked in 24 minutes using $112.50 \mathrm{ml}$ of kerosene fuel with a monthly expenses of Php 628.20 and a 750 fresh chicken was fried-cooked in 26 minutes using $120 \mathrm{ml}$ of kerosene fuel

Table 1. The thermal efficiency of rice hull stove*

\begin{tabular}{ccccc}
\hline Foods & $\begin{array}{c}\text { Energy needed } \\
(\mathrm{kCal} / \mathrm{hr})\end{array}$ & $\begin{array}{c}\text { Energy input } \\
(\mathrm{kg} / \mathrm{hr})\end{array}$ & $\begin{array}{c}\text { Heat energy input } \\
(\mathrm{kCal})\end{array}$ & Thermal efficiency (\%) \\
\hline Clean rice & 161.429 & 0.359 & 79.300 & $9.76 \%$ \\
Drinking water & 1152.000 & 2.560 & 43.200 & $23.06 \%$ \\
Vegetables & 407.104 & 0.136 & 74.500 & $11.33 \%$ \\
Fried fish & 58.489 & 0.130 & 28.250 & $11.33 \%$ \\
Fried chicken & 74.74 & 0.166 & 1215.000 & $15.40 \%$ \\
\hline
\end{tabular}

${ }^{*}$ The formulas and constant values are taken from Belonio's Rice Husk Handbook.

Table 2. Rice hull fuel.

\begin{tabular}{|c|c|c|c|c|c|c|c|}
\hline \multirow{2}{*}{ Foods/materials } & \multicolumn{2}{|c|}{ Weight } & \multicolumn{2}{|c|}{ Time } & \multicolumn{3}{|c|}{ Monthly expenses } \\
\hline & $\begin{array}{l}\text { Foods } \\
\text { (grams) }\end{array}$ & $\begin{array}{c}\text { Fuels } \\
\text { (grams) }\end{array}$ & $\begin{array}{c}\text { Firing } \\
\text { (seconds) }\end{array}$ & $\begin{array}{c}\text { Cooking } \\
\text { (minutes) }\end{array}$ & $\begin{array}{l}\text { Cost } \\
\text { (Php) }\end{array}$ & $\begin{array}{l}\text { Daily } \\
\text { (Php) }\end{array}$ & $\begin{array}{l}\text { Total } \\
\text { (Php) }\end{array}$ \\
\hline Clean rice & 1000 & 700 & & 21 & 0.00 & 0.00 & 0.00 \\
\hline Drinking water & 4000 & 600 & & 15 & 0.00 & 0.00 & 0.00 \\
\hline Vegetables & 1000 & 1000 & 15 to 45 & 11 & 0.00 & 0.00 & 0.00 \\
\hline Fried fish & 500 & 1013 & & 29 & 0.00 & 0.00 & 0.00 \\
\hline Fried chicken & 750 & 405 & & 34 & 0.00 & 0.00 & 0.00 \\
\hline & & & Total & & & & 0.00 \\
\hline
\end{tabular}


Table 3. Charcoal fuel* .

\begin{tabular}{|c|c|c|c|c|c|c|c|}
\hline \multirow{2}{*}{ Foods/materials } & \multicolumn{2}{|c|}{ Weight } & \multicolumn{2}{|c|}{ Time } & \multicolumn{3}{|c|}{ Monthly expenses } \\
\hline & $\begin{array}{l}\text { Foods } \\
\text { (grams) }\end{array}$ & $\begin{array}{c}\text { Fuels } \\
\text { (grams) }\end{array}$ & $\begin{array}{c}\text { Firing } \\
\text { (seconds) }\end{array}$ & $\begin{array}{l}\text { Cooking } \\
\text { (minutes) }\end{array}$ & $\begin{array}{l}\text { Cost } \\
\text { (Php) }\end{array}$ & $\begin{array}{l}\text { Daily } \\
\text { (Php) }\end{array}$ & $\begin{array}{l}\text { Total } \\
\text { (Php) }\end{array}$ \\
\hline Clean rice & 1000 & 500 & & 40 & 6.25 & 18.75 & 562.25 \\
\hline Drinking water & 4000 & 200 & & 8 & 2.50 & 7.50 & 225.00 \\
\hline Vegetables & 1000 & 400 & 1 to 38 & 28 & 5.00 & 15.00 & 450.00 \\
\hline Fried fish & 500 & 225 & & 16.88 & 2.85 & 8.55 & 256.50 \\
\hline Fried chicken & 750 & 375 & & 25.32 & 4.75 & 14.25 & 427.00 \\
\hline & & & Total & & & & 1920.75 \\
\hline
\end{tabular}

*Php 12.50 per kgs.

Table 4. Kerosene fuels* .

\begin{tabular}{|c|c|c|c|c|c|c|c|}
\hline \multirow{2}{*}{ Foods/materials } & \multicolumn{2}{|c|}{ Weight } & \multicolumn{2}{|c|}{ Time } & \multicolumn{3}{|c|}{ Monthly expenses } \\
\hline & $\begin{array}{l}\text { Foods } \\
\text { (grams) }\end{array}$ & $\begin{array}{l}\text { Fuels } \\
(\mathrm{ml})\end{array}$ & $\begin{array}{c}\text { Firing } \\
\text { (seconds) }\end{array}$ & $\begin{array}{c}\text { Cooking } \\
\text { (minutes) }\end{array}$ & $\begin{array}{l}\text { Cost } \\
\text { (Php) }\end{array}$ & $\begin{array}{l}\text { Daily } \\
\text { (Php) }\end{array}$ & $\begin{array}{l}\text { Total } \\
\text { (Php) }\end{array}$ \\
\hline Clean rice & 1000 & 151.25 & & 37.5 & 9.38 & 26.14 & 784.20 \\
\hline Drinking water & 4000 & 34.50 & & 34.4 & 2.14 & 6.42 & 192.60 \\
\hline Vegetables & 1000 & 101.34 & 1 to 40 & 22.0 & 6.29 & 16.87 & 506.10 \\
\hline Fried fish & 500 & 112.50 & & 24.0 & 6.98 & 20.94 & 628.20 \\
\hline Fried chicken & 750 & 120.00 & & 26.0 & 7.44 & 22.32 & 669.60 \\
\hline & & & Total & & & & 2780.70 \\
\hline
\end{tabular}

*Php 62.00 per liter.

with a monthly expense of Php 669.60.

Table 5 shows that rice hull fuel has no expenses. Charcoal fuel yields an annual expense of Php 23049.00 while kerosene fuel yields an annual expense of Php 33368.40.

\subsection{Benefit Cost Analysis}

This design is economical compared to other biogas stoves in the market. The cost of other products range from P2500.00 to P7500.00 for cooking using firewood, charcoal and LPG. In this stove, the cost for 1 kilogram rice hull fuel capacityis only Php 1500.00 (US \$37.50) and for the 500 grams rice hull fuel capacity cost, it is only Php 1200.00 (US \$30.00).

Other designs of bio-fuel stoves have fixed burners (inside and outside). This design is unique and advantageous to the users because its inside burner that costs Php 300.00 can be replaced manually every 18 months of operation and 24 months for the (outside burner) in operation. For the replacement of the outside burner, its materials only cost Php 500.00.

The return of investment (ROI) per stove is 0.47 percent, three times a day in 2 hours utilization. Its payback period (PP) is 0.98 years and the internal rate of return (IRR) is 0.45 percent.

Figure 3 shows the differentiation of fuels (charcoal, kerosene and rice hull) in monthly and yearly expenses in cooking operations: (clean rice, drinking water, vegetables, fried fish \& fried chicken) at different food weights, time of cooking, and fuel weight.

\section{Conclusion and Recommendation}

The experimental method of research was used. The researcher was responsible for the purchase of the materials needed for the study. 
Table 5. Monthly/yearly fuel expenses in cooking.

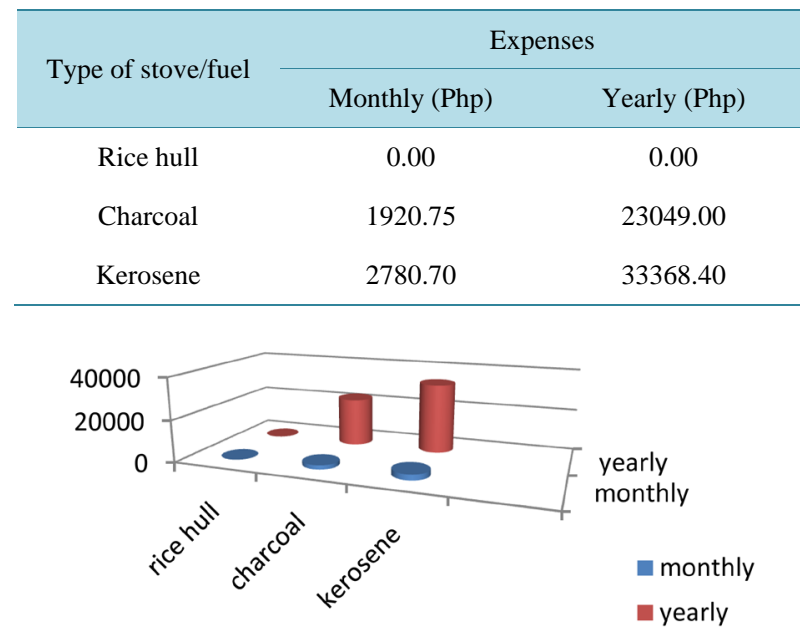

Figure 3. Monthly and yearly expenses using rice hull, charcoal and kerosene stove.

\subsection{Conclusions}

Based on the findings of the study, the following conclusions were derived:

The study utilized experimental research method which included the materials and equipment used, research design and layout, fabrication procedures, testing procedures, data analysis and benefit/cost analysis.

1) The materials used in assembling the rice hull stove were steel bars, flat bars steel plates, tie wire, and the equipments used were portable welding machine 160 - $300 \mathrm{amp}$, welding mask (full face \& goggle type), bench vise (square and round), stationary/bench electric drill, portable hand electric drill, portable hand grinder, stationary/bench hand "Z" cutter, air compressor w/spray paint, hacksaw, anvil no. 6, C-clamp, Ball-pen hammer (small, medium, large), and thinner snips.

2) The research design and layout were based on its portability and light weight, and its ease in operation. The features of this portable rice hull stove are as follows:

a) The stove weight is 5.75 kilograms; measuring of $70 \mathrm{~cm}$ in height, $47 \mathrm{~cm}$ width for a 1 kilogram stove capacity and for the 500 grams capacity stove, weigh is $4.1 \mathrm{~kg}, 40 \mathrm{~cm}$ in height, and $40 \mathrm{~cm}$ in width respectively.

b) Its body configuration is an expanded cone/funnel appearance. A movable leverage is welded at the bottom/ash chamber part of the stove for releasing the ashes and providing aeration to the machine. This is made of galvanized iron steel plate, gauge 22, and corrugated steel bars sized of $10 \mathrm{~mm}$ and $8 \mathrm{~mm}$, respectively.

c) A cone/funnel type hopper is attached to the top portion of the stove that serves as guide in loading the rice hull as fuel.

d) The tripod/base was made of steel bar with dimension of $10 \mathrm{~mm}$ in diameter and $70 \mathrm{~cm}$ in height that serves as foundation of the equipment.

e) The inside burner is detachable for easy replacement with perforated sides for adequate aeration.

This stove takes only 15 minutes for 2 liters in boiling water; 21 minutes in cooking 1 kg rice; 29 minutes in cooking $1 / 2 \mathrm{~kg}$ of fried fish; and 11 minutes in cooking vegetables.

3) Fabrication procedures. Based on the plans and design, the steel bar and galvanized steel plate was cut to its desired length then welded to form the tripod/base; the combustion chamber was designed with perforated holes inside and outside cover to have an air passage to the rice hull. Guide/stopper of rice hull fuel was constructed to prevent obstruction at the burner or topmost portion of the combustion chamber.

4) Testing procedure. Testing was undertaken to determine the workability of the stove. The completed cooking stove was tested using the rice hull as fuel by pouring the rice hull into the combustion chamber in full capacity to the topmost portion of the hopper. Seven pieces of scratch coupon bond were used to ignite the rice hull fuel for 15 to 45 seconds of ignition.

5) Data analysis. The stove was tested with various cooking materials and the data were gathered and recorded for computations and completion of the research. 
6) Benefit and cost analysis. This design is economical compared to other biogas stoves in the market. The cost of other products ranges from P2500.00 to P7500.00 for cooking using firewood, charcoal and LPG. In this stove, the cost, for 1 kilogram rice hull fuel capacity, is only Php 1500.00 (US \$37.50); and for the 500 grams rice hull fuel capacity, it is only Php 1200.00 (US \$30.00).

Other designs of bio-fuels stoves have fixed burners (inside and outside). This design is unique and advantageous to the users because the inside burner that costs Php 300.00 can be replaced manually every 18 months of operation and 24 months for the outside burner in operation. For replacing the outside burner, its materials only cost Php 500.00.

The return of investment (ROI) per stove is 0.47 years, three times a day in 2 hours utilization. Its payback period (PP) is 0.98 years and the internal rate of return (IRR) is 0.45 years.

\subsection{Recommendations}

The findings of this study have an important implication for future enhancement and improvement of the study.

- It is recommended that this portable rice hull stove must be used in every Filipino household particularly farmers in the countryside of the Philippines to save time, investment in their daily routine cooking operations and most of all our environment;

- For small time businesses establishment like chicken joy, and roasting of lechon, this portable rice hull stove are encouraged so as to provide this machine so that they can save money and labor in their daily cooking operation;

- It is recommended also that this study can be replicated but additional features for controlled operation and replaceable outside burner be included; and

- It is further recommended that this study be upgraded for gasification process to purify the golden flame to bluish flame gas output.

\section{Acknowledgements}

This research work would not have been realized without the guidance of the Almighty God.

Likewise, the researcher wishes to thanks the following:

To Dr. Tito M. Cabili and Staff, Research Director, Dr. Ronelie Salvador, Dr Karina Milagros R. Cui and Mr. Julio Calumpiano, Jr. members, R \& D In-House Review; Engr. Rommel P. Noble, ILWARM Director, and the shop personnel;

Dr. Rolando A. Delorino, VP for Research and Extension Services and Training, Chair, R \& D In-House Review panel; and Atty. Mar. P. De Asis, PhD, President, for giving me full supports and enthusiasm in this field of endeavor;

Dr. Norman T. Diaz, Chair, Board Director-Northern Samar Development Workers Cooperative, for mass ordering/purchasing this stove. Moreover, he is indebted to Mr. Ricardo De Guia Jr. for his suggestion in the realization of this project and to Prof. Villa C. Carpio for editing this manuscript.

Those who contributed much for the success of this study, particularly my wife, Gigi and children, my friends \& colleagues, thank you.

\section{References}

[1] McClelland, D.C. (1999) Management Theories and Practices. Academic Publishing House Corporation.

[2] Belonio, A.T., Belonio, D.A.H. and Larano, L. (2005) Rice Husk Gas Stove Handbook. Appropriate Technology Center. Central Philippine University, Iloilo City, 67-76.

[3] http://www.knowledgebank.irri.org/step-by-step-production/postharvest/milling/what-is-rice-husk

[4] Zafar, S. (2013) Bioenergy Development in Malaysia. http://bioenrgyconsult.com/tagrice-husk/

[5] Beagle, E.C. (1978) Rice Husk Conversion to Energy. Rome, FAO. Agricultural Services Bulletin No. 31.

[6] Bautista, E.U., Aldas, R.E. and Gagelonia, E.C. (2013) Rice Hull Furnaces for Paddy Drying: The Philippine Rice Research Institute Experience. http://aciar.gov.au/files

[7] Pare, M. (2011) Cooking with Rice Hulls: A Primer on Current Technology, Projects and Challenges. http://www.vrac.iastate.edu/ethos/files

[8] Belonio, A. and Edward, L. (2011) Simplified Design of the Batch Type Rice Husk Gas Stove. 
http://www.aprovecho.org/lab/rad121/stove-design/doc/190/raw

[9] Lockman, I., Pare, M., Jordan, E., Vo, J., Nguyen, P. and Tyler, W. (2010) Design of a Rice Husk Gasification Cook Stove for Rural Nicaragua. Mechanical Engineering and Industrial Design, Georgia Institute of Technology (GIT). http://www.old.me.gatech.edu/jonathan.colton detm/stovefind report.pdf 